\title{
Root Anatomy of Nine Orchidaceae Species
}

\author{
Virginia del Carmem Oliveira and Maria das Graças Sajo* \\ Depto de Botânica, IBUNESP, Rio Claro, Caixa Postal 199. 13506-900 Rio Claro - SP - Brasil
}

\begin{abstract}
Studies on the root anatomy of nine Orchidaceae species presented a multisseriated velamen, a parenchymatous cortex and a definided endodermis, in all the studied species (Catasetum fimbriatum Lindl., Dichaea bryophila Rchb. f., Encyclia calamara_(Lindl.) Pabst, Epidendrum campestre Lindl., Epidendrum secundum Jacq., Miltonia flavescens Lindl., Pleurothallis smithiana Lindl., Stanhopea lietzei (Regel) Schltr. and Vanda tricolor Lindl.) Structural characters, which could be considered root adaptations to an epiphytic habit, were also common for all species.
\end{abstract}

Key words: root anatomy, Orchidaceae, ephiphytism, structural characters

\section{INTRODUCTION}

Orchidaceae is one of the largest families of flowering plants, and represents the most developed group of the superorder Liliiflorae. They exhibit many specialised features to attract and to deceive insects, approaching crossed pollination. Although its flowers present a relatively uniform structure, the organization of vegetative parts are notably variable among species (Dressler, 1993). Such features allow the family to thrive in different environments, and increase the number of its different grow forms (Pabst \& Dungs, 1975).

The family is also considered notable by its capacity to explore the epiphytic habitat (Benzing, 1986; Benzing et al., 1982), with vegetative specialisation related to storage of water and minerals, which are scarce and transitory in such habitat. One of these specialization, in the roots, is the presence of a multisseriated epidermis, the velamen, which absorbs water and minerals, reduces transpiratory rates, and offers mechanical protection (Pridgeon, 1986; Benzing, 1987).

The orchids, as all monocotyledons, have a root system formed by adventitious roots which originate in the stem. In the epiphytic species, the aerial roots emerge from the rhizome, are grey in colour with a green apex and are covered by the velamen. Sometimes, such roots form great, entangled nidles, which accumulate organic compounds used by the plant (Hoehne, 1940).

This study describes the anatomical structure of the roots, in nine species of orchids, with the purpose of recognising features that are possibly related to epiphytic habitats.

\section{MATERIAL AND METHODS}

The material was obtained from the collection of orchids of the Instituto de Botânica de São Paulo (IBT), registered as follow: Catasetum fimbriatum Lindl. 3741, Dichaea bryophila Rchb. f. 13955, Encyclia calamara (Lindl.) Pabst 16, Epidendrum campestre Lindl. 7063, Epidendrum secundum Jacq. 4780D, Miltonia flavescens Lindl. 6473, Pleurothallis smithiana Lindl. 607, Stanhopea lietzei (Regel) Schltr. 3469 and Vanda tricolor Lindl. 11500.

Median region of the roots were fixed in FAA 50 and transferred to alcohol 50\% (Johansen, 1940). For the anatomical study, freehand sections were stained with astra blue and basic fucsin (Roeser, 1962). The starch was identified by Lugol Solution (Bücherl, 1962); the lignin by

\footnotetext{
* author for correspondence
} 
acidified floroglucin solution (Johansen, 1940); lipids by Sudan III (Johansen, 1940), and flavonoids by potassium hydroxide (Costa, 1982). The photomicrographs were obtained in a Olympus photomicroscopy.

\section{RESULTS AND DISCUSSION}

The roots of all studied species were cylindrical and similar in structure, although some of them were thicker, as of Vanda tricolor (Fig. 1) and others thinner, as of Pleurothallis smithiana (Fig. 4). The velamen was formed by dead cells, which could be polygonal, elliptic or rectangular, in cross section (Fig. 1,4,7,11-13). The velamen was also found in others monocotyledons such as Araceae, Liliaceae, Dioscoreaceae, Taccaceae, Amarillidaceae and Commelinaceae (Dahlgren \& Clifford, 1982). Its occurrence was associated to the epiphytic habit (Engard, 1944; Dycus \& Knudson, 1957), although it also occured in terrestrial orchids (Porembski \& Barthlott, 1988; Stern et al., 1993a; Stern et al., 1993b; Kurzweil et al., 1995) and could be lacking in some orchids (Singh, 1986).

The cells of the outer velamen layer were periclinally flattened, while underlying cells were radially enlarged, in cross section (Fig 7,11-13,16). As in other epiphytic species (Withner, et al., 1974), the outer velamen layer has hairs in the root of Pleurothallis smithiana (Fig. 4); in this root the suberized thickening, observed between the two cellular layers of the velamen (Fig. 5), were absent in the contact region with root hairs. Such absence could be related to the efficiency of the absorptive process. In Catasetum fimbriatum (Fig. 12) and Stanhopea lietzei (Fig. 13), the outer velamen layer was formed by smaller cells and represents the epivelamen, which according to Shushan (1959) has the same origin as the deepest layers.

The velamen was bistratified in roots of characteristic wall thickening. They were the covering cells, observed by Engard (1944) in other orchids, which aid in the condensation of water and other gases (Pridgeon, 1987).
Pleurothallis smithiana (Fig. 4) and Pleurothallis rupestris (Scatena \& Nunes, 1996). However, according to Pridgeon (1982; 1987), Pleurothallis alexandrae has a velamen with 3-4 layers of cells, showing that the number of layers in the velamen can vary within the same genus. Stern \& Morris (1992) considered the number of cellular layers of taxonomic value only for species with unisseriated velamen.

As in Pleurothallis smithiana, the velamen was bistratified in roots of Dichaea bryophila (Fig. 8-9); however, the velamen showed up to 15 layers (Table 1) in Catasetum fimbriatum (Fig. 12) and Stanhopea lietzi (Fig. 13). The size of the velamen could be related to environmental factors, especially to water and temperature. Therefore, species from dry environments or exposed habitats have a velamen with many layers, and those from humid environments have a single layered velamen, or only an epivelamen (Sanford \& Adanlawo, 1973).

The velamen cell walls presented different patterns of secondary thickening, which could form wide lines, as in Vanda tricolor (Fig. 1-2) and Pleurothallis smithiana (Fig. 5), or a reticulum of fine lines, as in Stanhopea lietzei (Fig. 15) and Epidendrum campestre. The composition of velamen cell walls was cellulosic, with different degrees of lignin and suberin impregnations, depending on the species (Benzing et al., 1983; Noel, 1974). In most of the species studied, the velamen cells walls had suberin impregnation with lignified thickenings. A function, attributed to the velamen cell wall thickenings, is to provide mechanical support, avoiding cellular collapse during dehydration (Noel,1974).

In Vanda tricolor (Fig. 1), Epidendrum campestre (Fig. 16) and Epidendrum secundum roots (Fig. 17), some cells of the inner velamen layer were divided, cuneiforms and presented a

The outer layer of cortex, close to the velamen, was differentiated in an exodermis which presented two types of cells: higher cells, according to the root axis, with thickened walls and no protoplast, and isodiametric shorter cells 
with thin walls (Fig. 3,9). These latter ones, were the passage cells, which have a dense cytoplasm and proeminent nucleus. The longer suberified/lignified cells of the exodermis protect the root cortex against dehydration, while the shorter cells, with thin walls, drive nutritive compounds from the velamen to the root cortex (Haberlandt, 1914). In cross section, the higher exodermis cells showed three different patterns of secondary wall thickenings (Table 1): U shaped - outer and radial walls thickened (Fig. 16), O shaped - all walls thickened (Fig. 1,4,7,11), or only the outer walls thickened (Fig. 8,12,13).

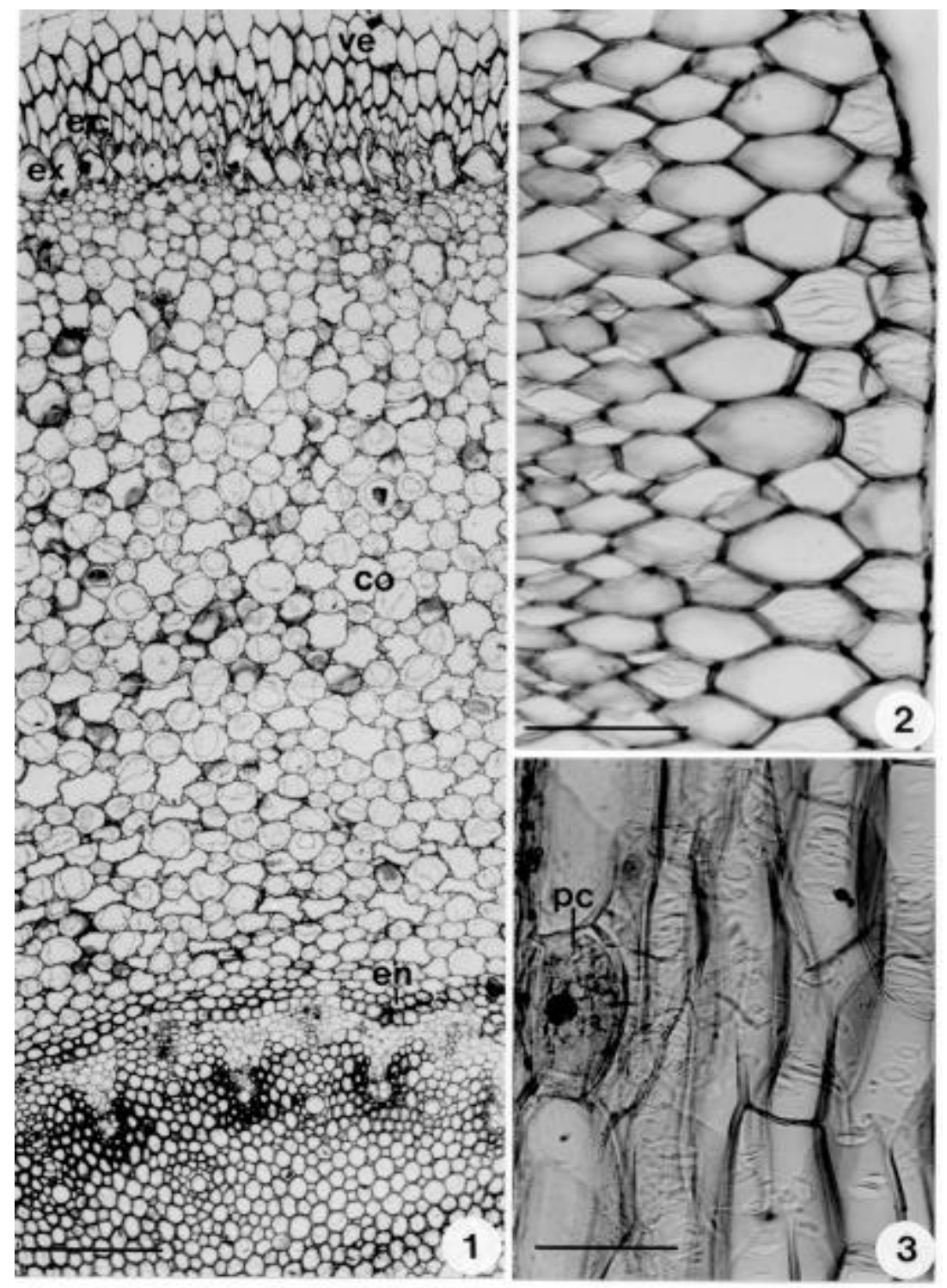

Figures 1-3. Root of Vanda discolor. 1. Cross-section at median region, showing covering cells in the velamen (cc). 2. Velamen in cross-section with wide line thickenings in the cell wall. 3. Exodermis and inner velamen layers in longitudinal section. co-cortex; en-endodermis; ex-exodermis; pc-passage cell; ve-velamen. Bars: 1= 250 $\mu \mathrm{m}$; $2=100 \mu \mathrm{m} ; 3=50 \mu \mathrm{m}$.

The velamen/exodermis complex absorbs passively and maintains humidity temporarily. So, according to Benzing \& Friedman (1982), it was similar to trichomes of Bromeliaceae leaves and formed a complementary absorptive system. Probably, for this reason, different species living in a similar environment, present complementary adaptations in the velamen- 
exodermis system. It was the case of Epidendrum campestre and Catasetum fimbriatum that occured in sunny environments under dry conditions. In the former, the velamen was composed of few cellular layers and the exodermis cell walls were lignified (Fig. 16); in the later, the velamen was thicker and the exodermis cell walls were thinner (Fig. 12).

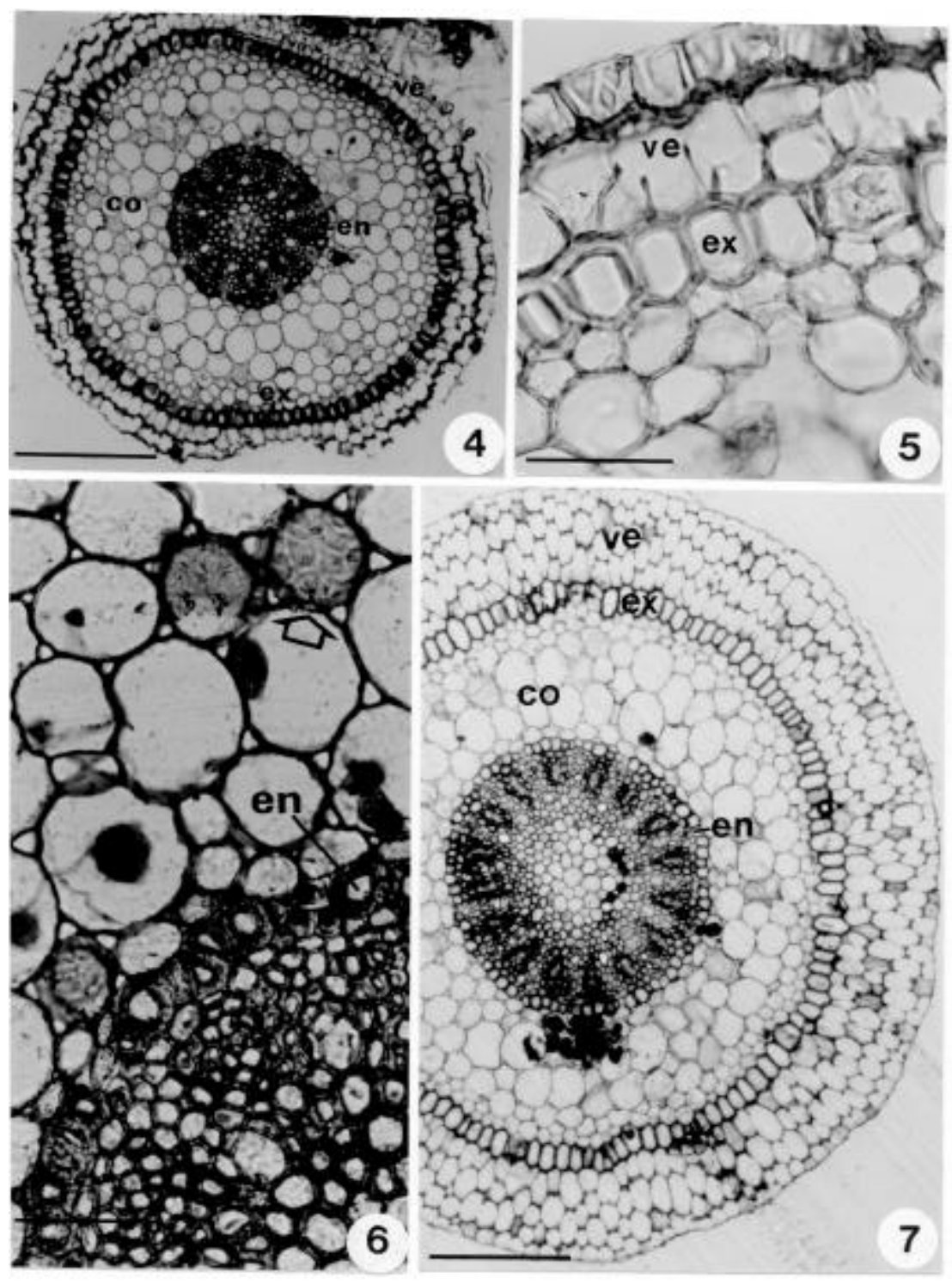

Figures 4-6. Root of Pleurothallis smithiana in cross-section. 4. General aspect of the median region, with epidermal hairs and ectomycorrizae. 5. Velamen with suberified thickening between its two layers and wide line thickenings in the cell walls. 6. Cortex with tracheoidal elements (arrow) and thickened endodermis cell walls (Oform). Figure 7. Root of Encyclia calamara in cross-section with many drops of flavonoid compounds in the cortex. co-cortex; en-endodermis; ex-exodermis; ve-velamen. Bars: 4,7=250 $\mu \mathrm{m} ; 5,6=50 \mu \mathrm{m}$.

In all roots studied, the cortex was relatively thickened and the number of its cellular layers varied among species (Table 1); it was formed by round cells, of various sizes and thin walls (Fig. 1,4,7-8,11-13,16). The cortical cell layers close to the exodermis and endodermis were smaller than those of the central region. In Pleurothallis smithiana (Fig. 6), Stanhopea lietzei (Fig. 13) and Catasetum fimbriatum some cells of the root cortex had reticulated wall thickenings. Such cells, called tracheoidal elements, were also present in roots of Cattleya 
(Sushan, 1959) and of other Stanhopea species (Stern \& Morris 1992). According to Olatunji \& Nengim (1980) the presence of secondary thickening in these cell walls suggested that they had mechanical support and water storage functions.

Encyclia calamara roots showed some cortical cells with dark flavonoids compounds (Fig. 7), like other species of the genus (Pabst et al.,
1980). Such compounds were useful against herbivores and associate with free radicals, which were frequent in plants living under certain stress (Yamasaki et al., 1997). Idioblasts with raphids are common in root cortex of the studied species. According to Shushan (1959), idioblasts with raphids were formed by an unequal division in the fundamental meristem cells, and could be related to the osmotic balance of the plant (Bonates, 1993).
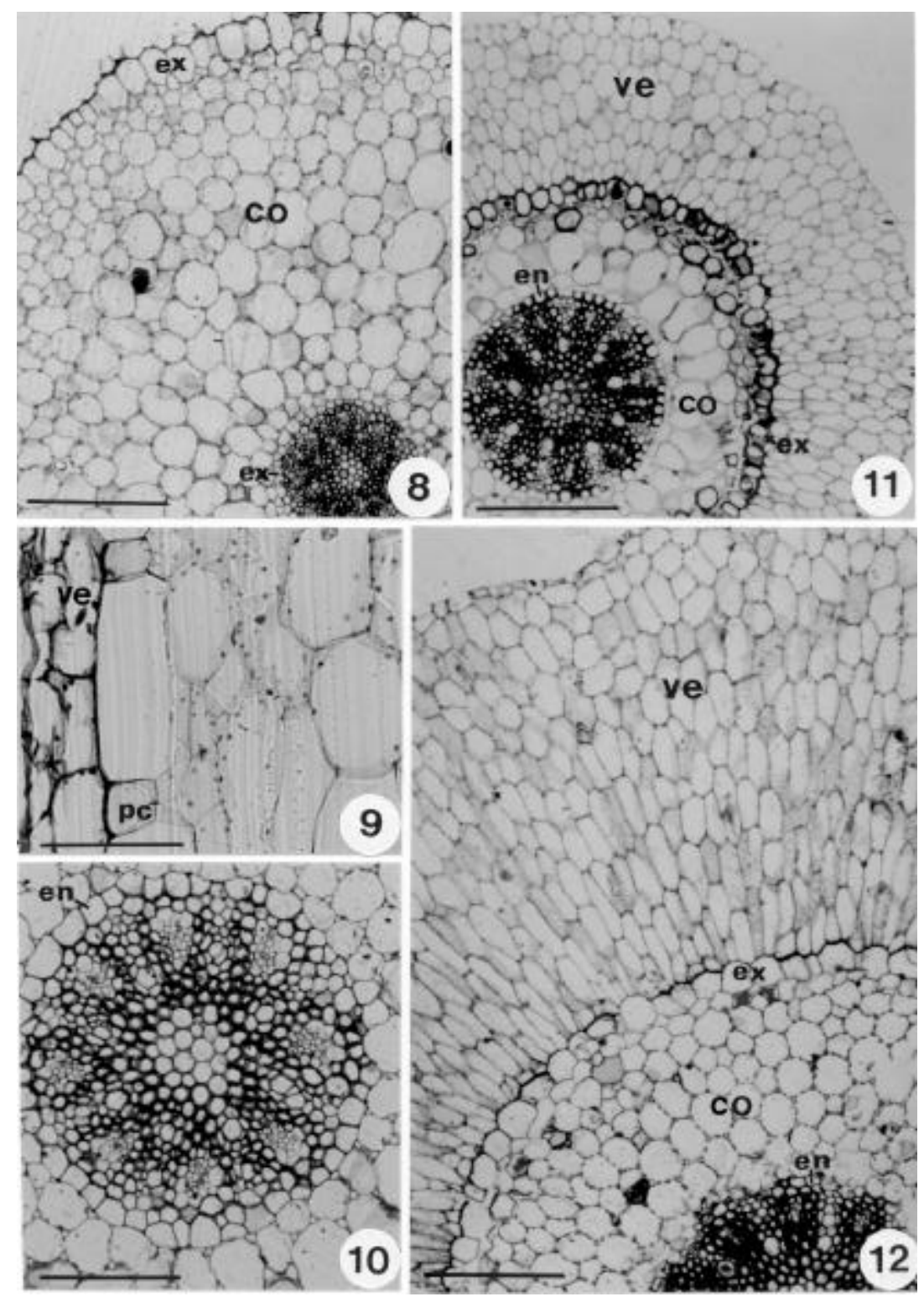

Figures 8-10. Root of Dichaea bryophila. 8. Cross-section at the median region. 9. Two layered velamen and exodermis in longitudinal section. 10. Cross-section at the central cylinder showing endodermis cells with the outer walls thickened. Figures 11-12. Roots in cross-section at the median region. 11. Miltonia flavescens. 12. Catasetum fimbriatum. co-cortex; en-endodermis; ex-exodermis; pc-passage cell; vevelamen. Bars: $8,11,12=250 \mu \mathrm{m}$; $9,10=100 \mu \mathrm{m}$. 
The root cortex of Epidendrum campestre presented hiphae of fungus (Fig. 16), similar to those described by Benzing (1981). In Pleurothallis smithiana roots, the fungi were only in contact with the root surface (Fig. 4) and represented the ectomycorrizae described by Dressler (1981). The orchid-fungus relationship were a fundamental condition for seed

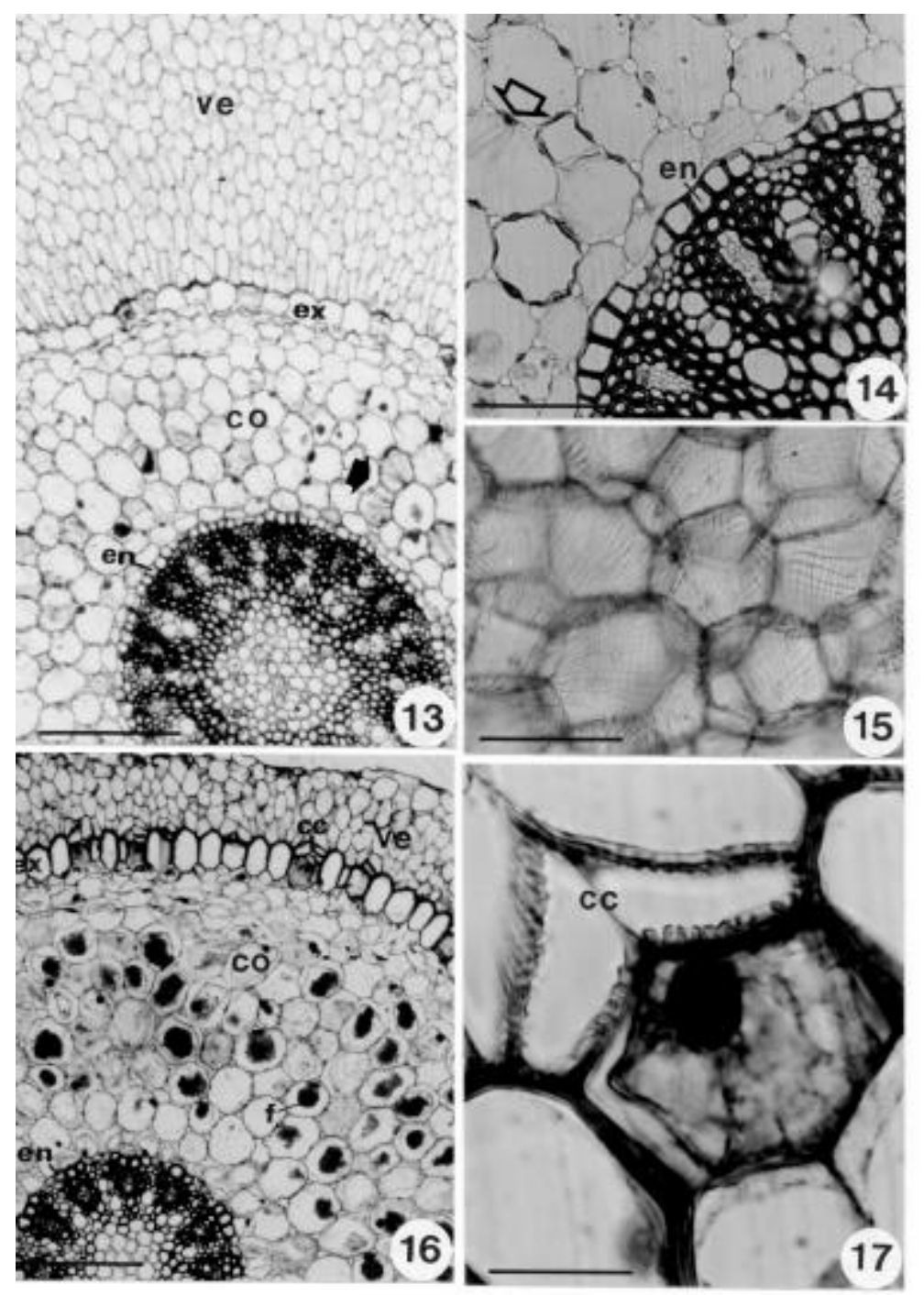

Figures 13-15. Cross-section of Stanhopea lietzei root at the median region. 13. General aspect. 14. Tracheoidal elements in the cortex (arrow) and endodermis with thickened cell walls (O-form). 15. Velamen with fine line thickenings in the cell walls. Figure 16. Cross-section of Epidendrum campestre root, with covering cells in the velamen (cc) and fungus in the cortical region (f). Figure 17. Covering cell in the velamen of Epidendrum elongatum root, close to a exodermis passage cell. co-cortex; en-endodermis; ex-exodermis; ve-velamen. The arrow show tracheoidal element. Bars: $13,16=250 \mu \mathrm{m} ; 14=100 \mu \mathrm{m} ; 15,16=50 \mu \mathrm{m}$

germination and plant establishment; a lot of species maintained this association for a lifetime while others became independent as adults (Arditti, 1967; Sanford, 1974). According to Sanford (1974), the orchids dependence on such association were partially saprophytic, because the fungus supplied the organic compounds for diffusion instead of active transport.

In most of the roots studied, an unisseriated endodermis formed a sheath around the vascular cylinder (Fig. 4,7,8,10-13,16); however, it was bisseriated in Vanda tricolor (Fig. 1), as 
observed by Rosso (1966) in species of the genus Paphiopedilum and Phragmipedium which was caused by an intrusive abnormal growth.

The endodermis cells walls were thickened in an U shape, in Dichaea bryophila (Fig. 8,10), and in an $\mathrm{O}$ shape, in the other studied species (Fig. 1,4, 6,7,11-14,16). The 1-3 endodermis cells, opposite to the protoxylem poles, were small, had thin walls and were called passage cells.

All studied roots had an unisseriated pericycle and were poliarchs; the number of protoxylem poles varied, according to the species (Table 1). Some roots, like those of Vanda tricolor, had many protoxylem poles and were thick (Fig. 1), while others, like those of Pleurothallis smithiana and Dichaea bryophila, presented only few protoxylem poles and were thin (Fig. $4,8,10)$. A close correlation probably existed between root diameter and number of protoxylem poles. Internal to the vascular tissues there was a parenchymatous tissue (Fig. $1,4,7,8,10-13,16) ;$ in Vanda tricolor root metaxylem elements were observed in a central position.

$\underline{\text { Table I. Anatomycal features in the roots of nine orchidaceae studied }}$

\begin{tabular}{lccccc}
\hline Species & $\begin{array}{c}\text { Velamen } \\
\left(\mathbf{n}^{\mathbf{0}} \text { of cell layers }\right.\end{array}$ & $\begin{array}{c}\text { Exodermis } \\
\text { (wall thickening) }\end{array}$ & $\begin{array}{c}\text { Cortex } \\
\left(\mathbf{n}^{\mathbf{0}} \text { of cell layers }\right.\end{array}$ & $\begin{array}{c}\text { Endodermis } \\
\text { (wall thickening) }\end{array}$ & $\begin{array}{c}\text { Protoxylem } \\
\left(\mathbf{n}^{\mathbf{0}} \text { of poles) }\right.\end{array}$ \\
\hline Pleurothallis smithiana & 2 & $\mathrm{O}$ - form & $5-6$ & $\mathrm{O}$ & 9 \\
Epidendrum secundum & $5-6$ & $\mathrm{O}$ - form & $10-12$ & $\mathrm{O}$ & 17 \\
Epidendrum campestre & $5-6$ & $\mathrm{U}$ - form & $9-11$ & $\mathrm{O}$ & 11 \\
Encyclia calamara & $3-4$ & O - form & $5-6$ & $\mathrm{O}$ & 16 \\
Vanda tricolor & $5-6$ & $\mathrm{O}$ - from & $33-35$ & $\mathrm{O}$ & 34 \\
Dichaea bryophila & 2 & Ot & $11-12$ & $\mathrm{U}$ & 9 \\
Catasetum fimbriatum & $10-14$ & Ot & $7-8$ & $\mathrm{O}$ & 10 \\
Stanhopea lietzei & $12-15$ & Ot & $7-9$ & $\mathrm{O}$ & 12 \\
Miltonia flavescens & $5-7$ & O - form & $5-6$ & $\mathrm{U}$ & 9
\end{tabular}

Exodermis: U-form: outer and radial walls thickened; O-form: all walls thickened; Ot: only the outer walls thickened. Endodermis: O:all walls thickened; U: radial and inner walls thicke.

Besides the presence of a thick or thin velamen, with different shapes of cell wall thickenings, most of the studied roots showed some anatomical features, especially in the epidermis and cortex, which could be related to water absorption/storage. In Vanda tricolor, Epidendrum secundum and Epndrum campestre roots, some cells of the inner velamen layer were specially modified and could aid in water condensation. The hairs in the outer velamen layer of Epidendrum campestre increased the root surface for water absorption. The root cortex of Epidendrum campestre, Catasetum fimbriatum and Stanhopea lietzei showed tracheoidal elements, which had secondary wall thickenings and function in water storage. Also the flavonoids compounds present in the cortex of Encyclia calamara roots could be related to a hydric stress.

\section{ACKNOWLEDGEMENTS}

We thank Prof. Fabio de Barros, who provided and identified the material; we also thank $\mathrm{CNPq}$

for master fellowship grants for the senior author and for M.G. Sajo grant (Processo $\mathrm{n}^{0}$ 303296/84-4).

\section{RESUMO}

As raízes possuem um velame multisseriado, um córtex parenquimático e uma endoderme bem definida, em todas as Orchidaceae estudadas (Catasetum fimbriatum Lindl., Dichaea bryophila Rchb. f., Encyclia calamara (Lindl.) Pabst, Epidendrum campestre Lindl., Epidendrum secundum Jacq., Miltonia 
flavescens Lindl., Pleurothallis smithiana Lindl., Stanhopea lietzei (Regel) Schltr. e Vanda tricolor Lindl.). Caracteres estruturais, que podem ser considerados adaptações ao hábito epífito, são comuns nas raízes estudadas.

\section{REFERENCES}

Arditti, J. (1967), Factors affecting the germination of orchid seeds. Bot. Rev., 33 (1), 1-95.

Bonates, L.C.M. (1993), Estudos ecofisiológicos de Orchidaceae da Amazônia II. Anatomia ecológica foliar de espécies com metabolismo CAM de uma campina da amazonia central. Acta Amazonica, 23(4), 315-348.

Benzing, D.H. (1981), Micotrophy: its occurrence and possible significance among epiphytic Orchidaceae. Selbyana, 5 (3-4), 243-47.

Benzing, D.H. (1986), The vegetative basis of vascular epiphytism. Selbyana, 9, 23-43.

Benzing, (1987), D.H. Vascular epiphytism: taxonomic participation and adaptive diversity. Ann. Mo. Bot. Gard., 74 (2), 183204.

Benzing, D.H.; Ott, D.W.; Friedman, W.E. (1982), Roots of Sobralia macrantha (Orchidaceae): structure and function of the velamen-exodermis complex. Am. J. Bot., 69(4), 608-14.

Benzing, D.H.; Friedman, W.E.; Peterson, G.; Renfrow, A. (1983), Shootlessness, velamentous roots, and the pre-eminence of Orchidaceae in the epiphytic biotope. Am. $J$. Bot., 70(1), 121-33.

Bücherl, W. (1962), Técnica microscópica. São Paulo: Polígono.

Costa, A . F. (1982), Farmacognosia. 2 ed. Lisboa:Fundação Calouste Gulbenkian, 3.

Dahlgren, R.M.T.; Clifford, H.T. (1982), The monocotyledons: a comparative study. London: Academic Press.

Dressler, R.L. (1981), The orchids: natural history and classification. Cambridge, Massachusetts: Harvard University Press.

Dressler, R.L. (1993), Phylogeny and classification of the orchid family. Oregon: Deoscorides Press.
Dycus, A.M.; Knudson, L. (1957), The role of the velamen of the aerial roots of orchids. Bot. Gaz., 119, 78-87.

Engard, C.J. (1944), Morphological identity of the velamen and exodermis in orchids. Bot. Gaz., 105,457-62.

Haberlandt, G.F.J. (1914), Physiological plant anatomy. London: MacMillan Co.

Hoehne, F.C. (1940), Orchidaceaes. Flora Brasilica, 12, 1-254.

Johansen, D.A. (1940), Plant Microtechnique. New York: Mc Graw Hill.

Kurzweil, H. et al. (1995), Comparative vegetative anatomy and classification of Diseae (Orchidaceae). Bot. J. Linn. Soc., 117, 171-220.

Noel, A.R.A. (1974), Aspects of cell wall structure and development of the velamen in Ansellia gigantea Reichb. f. Ann. Bot., 38, 495-504.

Olatunji, O.A.; Nengim, R.O. (1980), Occurrence and distribution of tracheoidal elements in the Orchidaceae. Bot. J. Linn. Soc., 80, 357-70.

Pabst, G.F.J.; Dungs, F. (1975), Orchidaceae Brasiliensis I. Hildesheim, Brucke-Verlag. Kurt Schmerson.

Pabst, G.F.J.; Moutinho, J.L.A.; Pinto, A.V. (1980), Reestabelecimento do gênero Anacheillium Hoffmgg e revisão no gênero Hormidium Lindl. ex: Heynh. In: Anais do $1^{\circ}$ Encontro de Orquidófilos e Orquidólogos do Brasil. Rio de Janeiro, Expressão e Cultura,73-85.

Porembski, S.; Barthlott, W. (1988), Velamen radicum micromorphology and classification of Orchidaceae. Nord. J. Bot., 8(2), 117-37.

Pridgeon, A.M. (1982), Diagnostic anatomical characters in the Pleurothallidinae (Orchidaceae). Am. J. Bot., 69(6), 921-38.

Pridgeon, A.M. (1986), Anatomical adaptations in Orchidaceae. Lindleyana, 1(2), 90-101.

Pridgeon, A.M. (1987), The velamen and exodermis of orchid roots. In- Orchid biology: reviews and perspectives, ed. J. Arditti. Ithaca, New York: Cornell University Press, 139-92.

Roeser, K.R. (1962), Die nadel der schwarzkiefer massenprodukt und kunstwerk der natur. Mikrokosmos, 61(2), 33-6.

Rosso, S.W. (1966), The vegetative anatomy of 
the Cypripedioideae (Orchidaceae). J. Linn. Soc. (Bot.), 59, 309-41.

Sanford, W.W. (1974), The ecology of orchids. In- The orchids: scientific studies, ed. C.L. Withner. New York: Wiley, 1-100.

Sanford, W.W.; Adanlawo, I. (1973), Velamen and exodermis characters of West African epiphytic orchids in relation to taxonomic grouping and habitat tolerance. Bot. J. Linn. Soc., 66, 307-21.

Scatena, V.L.; Nunes, A.C. (1966), Anatomia de Pleurothallis rupestris Lindl. (Orchidaceae) dos campos rupestres. Bol. Botânica, Univ. São Paulo, 15, 35-43.

Shushan, S. (1959), Developmental anatomy of an orchid Cattleya $x$ Trimos. In- The orchids: scientific studies, ed. C.L. Withner. New York: Wiley, 45-72.

Singh, H. (1986), Anatomy of root in some Orchidaceae. Acta Botanica, 14, 24-32

Stern, W.L.; Morris, M.W. (1992), Vegetative anatomy of Stanhopea (Orchidaceae) with special reference to pseudobulb water-storage cells. Lindleyana, 7(1), 34-53.

Stern, W.L.; Morris, M.W.; Judd, W.S. (1993a), Comparative vegetative anatomy and systematics of Spiranthoideae (Orchidaceae). Bot. J. Linn. Soc., 113, 161-97.

Stern, W.L.; Cheadle, V.I.; Thorsch, J. (1993b), Apostasiads, systematic anatomy, and the origins of Orchidaceae. Bot. J. Linn. Soc., 111, 411-55.

Withner, C.L.; Nelson, P.K.; Wejksnora, P.J. (1974), The anatomy of orchids. In- The orchids: scientific studies, ed. C.L. Withner.. New York: John Wiley, 267-347.

Yamasaki, H.; Sakihama, Y.; Ikehara, N. (1997), Flavonoi-peroxidase reaction as a detoxification mechanism of plant cells against $\mathrm{H}_{2} \mathrm{O}_{2}$. Plant Physiol. 115, 1405-12.

Received: November 23, 1998; Revised: January 11, 1999; Accepted: June 17, 1999. 